\title{
(When) Do Anti-poverty Programs Reduce Violence? India's Rural Employment Guarantee and Maoist Conflict
}

\author{
Aditya Dasgupta* $\quad$ Kishore Gawande $^{\dagger} \quad$ Devesh Kapur $^{\ddagger}$
}

April 22, 2016

\begin{abstract}
Theory and extensive evidence connect poverty and underdevelopment to civil conflict, yet evidence on the impact of development programs on violence is surprisingly mixed. To break this impasse, we exploit a within-country policy experiment to examine the conditions under which anti-poverty programs reduce violence. The roll-out of India's National Rural Employment Guarantee Scheme caused a large long-run reduction in Maoist conflict violence, as measured with an original data set based on local language press sources. These pacifying effects were not uniform, however, but overwhelmingly concentrated in districts with sufficient pre-existing local state capacity to implement the program effectively. The results demonstrate the potential for anti-poverty programs to mitigate violent civil conflict by improving livelihoods, but also highlight the crucial role of state capacity in shaping these effects.
\end{abstract}

Word Count: 8,150

${ }^{*}$ PhD Candidate, Department of Government, Harvard University. Address: Department of Government, Harvard University, 1737 Cambridge Street, Cambridge, MA, 02138. Email: dasgupta@fas.harvard.edu

${ }^{\dagger}$ Century Club Professor in Business, Government and Society, University of Texas, Austin. Address: UT-Austin McCombs School of Business, 2110 Speedway, Stop B6000 Austin, TX 78712. Email: kishore.gawande@mccombs.utexas.edu

${ }^{\ddagger}$ Professor of Political Science and Director, Center for the Advanced Study of India, University of Pennsylvania. Address: Department of Political Science, University of Pennsylvania, 208 S. 37th Street, Room 217 Philadelphia, PA 19104-6215. Email: dkapur@sas.upenn.edu 


\section{Introduction}

More than half of all nations have experienced violent civil conflict since $1960 .^{1}$ Given theory and extensive evidence connecting poverty and underdevelopment to civil conflict around the world, ${ }^{2}$ whether development programs can reduce violence is a question of central interest to researchers and policy makers alike. ${ }^{3}$ However, current evidence on the impact of development programs on civil conflict is surprisingly mixed. Program evaluation studies variously find modest or null pacifying effects in Afghanistan, ${ }^{4}$ violence reducing effects in Iraq, ${ }^{5}$ violence increasing effects in the Philippines, ${ }^{6}$ and violence increasing effects in the case of foreign aid. ${ }^{7}$

Motivated by the mixed empirical record, we examine the conditions under which antipoverty programs reduce violence. We investigate a unique within-country policy experiment: the impact of the roll-out of the National Rural Employment Guarantee Scheme (NREGS), one of the world's largest anti-poverty programs, on India's Maoist conflict. In line with rebel opportunity cost and economic grievance theories, ${ }^{8}$ we argue that NREGS has plausibly mitigated the conflict by improving livelihoods - especially given the program's large impacts on rural poverty, which is an important factor in the Maoist insurgency. We refine existing theories and empirical tests, however, by highlighting the importance of state capacity in shaping the effects of anti-poverty programs on violence. When local state capacity is weak, program funds are unlikely to pass through to local populations and corruption may even reinforce local grievances with the state and provide opportunities for rebel financing. When local state capacity is strong, however, large-scale anti-poverty programs may substantially improve livelihoods, undercutting popular support for insurgency as well as economic incentives to participate in rebellion.

\footnotetext{
${ }^{1}$ Blattman and Miguel, 2010

${ }^{2}$ Collier and Hoeffler, 1998; Fearon and Laitin, 2003; Miguel, Satyanath and Sergenti, 2004

${ }^{3}$ Collier et al., 2003

${ }^{4}$ Beath, Christia and Enikolopov, 2013

${ }^{5}$ Berman, Shapiro and Felter, 2011; Iyengar, Monten and Hanson, 2011

${ }^{6}$ Crost, Felter and Johnston, 2014

${ }^{7}$ Nielsen et al., 2011; Besley and Persson, 2011; Nunn and Qian, 2014; Collier and Hoeffler, 2007

${ }^{8}$ Grossman, 1991; Collier and Hoeffler, 2004; Gurr, 1970; Sambanis, 2001
} 
Variation in state capacity, which exists across as well as within countries, ${ }^{9}$ could plausibly explain important but heretofore unexplained heterogeneity across settings in the effects of antipoverty programs on civil conflict.

To test the argument, we proceed in three steps. First, an important methodological contribution we make is to assemble a new district-level panel data set on Maoist conflict violence from multiple local language press sources (in Bengali, Hindi, Oriya, and Telugu). This alleviates significant under-reporting and urban and temporal reporting bias in other Maoist conflict data sets based on English language press sources. Our data set geo-codes attacks and deaths to districts over time, covering 144 districts between 1999 and 2009 across the six central and eastern 'red belt' states in which over $90 \%$ of Maoist conflict events and deaths occur.

Second, we employ a difference in differences identification strategy to estimate the effects of NREGS adoption on Maoist conflict violence. The staggered roll-out of the program over a three-year period across our sample of 144 districts enables us to compare changes in violence in districts adopting NREGS versus control districts. All specifications include district and year fixed effects which absorb time invariant omitted variables as well as common shocks and trends. We also control for the criteria utilized by the Indian government to assign districts to different phases of NREGS adoption. Taking these strategies, we show that that NREGS adoption caused a large long-run reduction in violence. The estimates suggest a roughly 60 percent reduction in violence, with this effect emerging primarily in the long-run. We provide evidence for the "parallel trends" identifying assumption by showing that violence fell with the adoption of NREGS and not prior to it. We also provide evidence that the adoption of NREGS was not 'bundled' with other development or counter-insurgency initiatives that may drive the results. Instead, NREGS reduced violence by improving rural livelihoods - which we demonstrate by showing that the program's pacifying effects were larger during poor-rainfall years, when rural communities are especially dependent on the program for supplemental income.

\footnotetext{
${ }^{9}$ O’Donnell, 1999; Migdal, 1988
} 
Third, we examine the role played by local state capacity in shaping these effects. Like many anti-poverty programs around the world, the implementation of NREGS is highly decentralized and dependent upon local state capacity, which varies widely across districts in India. To measure district-level state capacity, we use administrative data on NREGS employment provision and also construct a ranking of pre-existing local state capacity across districts based on average village-level access to four basic state services as measured in the 2001 census. This measure of local state capacity captures a district's pre-existing ability to fulfill basic functions of the state and is 'sticky' over time, predicting NREGS employment provision nearly a decade later. We show that NREGS's violence reducing effects were not uniform but overwhelmingly concentrated in districts in the top two quartiles of local state capacity. In these areas, violence fell with the adoption of NREGS and not prior, suggesting that it is the adoption of the antipoverty program in high-state capacity settings which drives the pacifying effects rather than state capacity on its own.

Our principal contribution is to use a within-country policy experiment and micro-level violence data to demonstrate the potential for anti-poverty programs to mitigate violent civil conflict. ${ }^{10}$ We refine existing theories and empirical tests by highlighting the role of state capacity in shaping the effects of anti-poverty programs on violence, helping to integrate competing theories about the relative salience of poverty versus state weakness in fueling conflict.(Collier and Hoeffler, 1998; Fearon and Laitin, 2003) The heterogeneous findings of existing studies may in part be driven by variation across settings in local capacity to implement development programs effectively. Finally, we contribute to the study of political violence in India and to the study of the Maoist insurgency specifically. ${ }^{11}$ Most closely related are two concurrent papers on the impact of NREGS on violence in India. ${ }^{12}$ We differ in two important ways: using local

\footnotetext{
${ }^{10}$ Kalyvas, 2008

${ }^{11}$ Brass, 1997; Weiner, 1978; Gayer and Jaffrelot, 2009; Varshney, 2003; Wilkinson, 2006; Staniland, 2014; Bhavnani and Lacina, 2015

${ }^{12}$ Fetzer, 2014; Khanna and Zimmermann, 2014
} 
language instead of biased English language violence data and highlighting the importance of local state capacity in shaping the effects of NREGS. ${ }^{13}$

The remainder of the paper is structured as follows. We first review theory and evidence on the impact of development programs on conflict and develop the argument about the importance of state capacity in shaping this relationship. We then describe the data and empirical strategy before reporting the results. The final section concludes.

\section{Theoretical Framework}

\section{Poverty, Conflict, and Development Programs}

A large theoretical literature argues that poverty and underdevelopment contribute to civil conflict. Broadly, these theories fall into two camps. One strand of theory takes the form of economic opportunity cost arguments, as articulated, for example, in Becker's canonical theory of crime. ${ }^{14}$ These theories hold that poverty and low returns to peaceful economic activity make participation in violent insurgency relatively more economically attractive and rebel recruitment therefore easier. ${ }^{15}$ A second strand of argumentation linking poverty to insurgency highlights the role of political grievances related to poverty in fueling support for insurgency. ${ }^{16}$ Poverty and weak public service delivery by the state can generate political grievances and delegitimize incumbent regimes, creating space for insurgencies. While the opportunity cost and

\footnotetext{
${ }^{13}$ We compare and contrast our results in greater depth in the body of the paper. In brief, we concur with Fetzer (2014) that NREGS caused a reduction in violence, though we show that this effect was present not only in districts experiencing droughts but also on average via an overall improvement of livelihoods. In contrast to our findings, surprisingly Khanna and Zimmerman (2014) conclude that NREGS caused no lasting impact upon violence. As we show, this is in part due to the fact that the English language source data set they utilize under-reports violence and is systematically biased toward reporting violence in more urban areas and in more recent years. When we replicate our analyses using the same biased English-language data, we predictably under-estimate the violence-reducing effects of NREGS as well. This comparison of results is fruitful in highlighting the methodological importance of using local language data sources to study rural civil conflict accurately.

${ }^{14}$ Becker, 1968

${ }^{15}$ Grossman, 1991; Collier and Hoeffler, 2004; Dal Bó and Dal Bó, 2011

${ }^{16}$ Gurr, 1970; Cederman, Gleditsch and Buhaug, 2013
} 
economic grievance channels differ slightly, both originate in poverty and underdevelopment as a root cause and predict that successful anti-poverty programs ought to reduce violence either by undercutting popular support for insurgency or by reducing the economic incentives to participate in rebellion.

Though extensive evidence has been amassed linking poverty and underdevelopment to conflict, ${ }^{17}$ the empirical evidence on the impact of development programs on conflict is significantly more mixed. Beath et al. find in a randomized control trial that the largest development program in Afghanistan improved perceptions of government but caused no or possibly a very modest reduction in violence. ${ }^{18}$ Crost et al. using a regression discontinuity design find that the KALAHI-CIDSS, a participatory local public goods program in the Philippines, increased violence in the early stages of program implementation due to rebel attempts to sabotage the program. ${ }^{19}$ Berman et al. find that CERP, a US military funded public services program in Iraq, reduced insurgent violence. ${ }^{20}$ However, they provide evidence that this was due not to an income channel but to a decidedly more Machiavellian strategy of conditioning access to the program in order gather intelligence on insurgent activity from civilians. Finally, several cross-national analyses find that foreign aid often increases conflict. ${ }^{21}$

These mixed empirical findings suggest that the salient question for research on development programs and civil conflict is not whether but under what conditions do these programs reduce violence. We refine existing theories and empirical tests by investigating scope conditions and contextual factors which might shape the extent to which development programs are effective at pacifying civil conflict. While many factors will plausibly generate heterogeneous effects, drawing on previous research, we focus on the design and quality of implementation of anti-poverty programs, which depends in large part upon state capacity, and discuss these

\footnotetext{
${ }^{17}$ Collier and Hoeffler, 1998; Fearon and Laitin, 2003; Miguel, Satyanath and Sergenti, 2004

${ }^{18}$ Beath, Christia and Enikolopov, 2013

${ }^{19}$ Crost, Felter and Johnston, 2014

${ }^{20}$ Berman, Shapiro and Felter, 2011

${ }^{21}$ Nielsen et al., 2011; Besley and Persson, 2011; Nunn and Qian, 2014
} 
factors in the context of NREGS and the Maoist conflict in India.

\section{The Role of State Capacity}

In order for anti-poverty programs to successfully mitigate violent conflict, programs must deliver perceptible improvements in livelihoods, on a scale sufficient to dis-incentivize participation in insurgency and bolster the legitimacy of the state vis-a-vis insurgent groups. However, even well-designed programs are frequently derailed by failure at the program implementation stage. Foreign aid has been found, for example, to be extremely 'leaky', with just a small fraction of funds reaching local populations. ${ }^{22}$ Domestic development programs also routinely fail at the implementation stage due to weak enforcement or elite capture. ${ }^{23}$

One of the most important determinants of policy implementation failure is weak state capacity, ${ }^{24}$ or an absence of the "ability of a government to administer its territory effectively". ${ }^{25}$ In weak state capacity settings, government is often captured by powerful societal elites who siphon funds in the form corruption. ${ }^{26}$ Moreover, in weak state capacity areas, bureaucracies lack the basic administrative capacity to absorb funds and deliver services. ${ }^{27}$

For these reasons, the effects of anti-poverty programs on violent civil conflict are likely to depend heavily upon state capacity, which varies not only across but within countries. ${ }^{28}$ Unfortunately, state capacity is often (but not always) weak in the very places where civil conflict is endemic. ${ }^{29}$ When local state capacity is weak, program funds are unlikely to pass through to local populations and corruption may even reinforce local grievances with the state and provide opportunities for rebel financing. When local state capacity is strong, however, anti-poverty

\footnotetext{
${ }^{22}$ Easterly and Pfutze, 2008

${ }^{23}$ Evans, 1995; Scott, 1969; Acemoglu and Robinson, 2012

${ }^{24}$ Johnson, 1982; Herbst, 2014; Centeno, 2002; Acemoglu, García-Jimeno and Robinson, 2015

${ }^{25}$ Skocpol, 1985

${ }^{26}$ Migdal, 1988; Bardhan and Mookherjee, 2000

${ }^{27}$ Keefer and Khemani, 2009; Fukuyama, 2004

${ }^{28}$ O’Donnell, 1999

${ }^{29}$ Fearon and Laitin, 2003
} 
programs may reduce violence as predicted by rebel opportunity cost and grievance theories of violent civil conflict. ${ }^{30}$ In these contexts, well designed anti-poverty programs have the potential to substantially improve livelihoods, undercutting popular support for insurgency as well as economic incentives to participate in rebellion.

\section{NREGS and the Maoist Conflict}

To test the argument, we examine a unique within-country policy experiment: the impact of India's National Rural Employment Guarantee Scheme, one of the world's largest anti-poverty programs, on the Maoist conflict, a protracted insurgency which was in 2010 termed by India's prime minister as the country's "biggest internal security challenge". Enacted in 2005 and rolled out across all rural districts in India between 2006 and 2008, NREGS guarantees each rural household up to 100 days of low-wage employment on local public works projects annually. Though NREGS is a national policy, it also serves as a pillar of the Indian government's strategy of combating the Maoist insurgency through development programs.

The roll-out of NREGS provides an excellent opportunity to test existing opportunity cost and grievance theories which suggest that anti-poverty programs can reduce violence. ${ }^{31}$ NREGS is far larger in scale than other programs previously studied in the conflict and development literature. NREGS is the largest rural anti-poverty program in India's history, with over 24 percent of India's rural households participating in the program according to a national sample survey conducted in 2009. ${ }^{32}$ Importantly, a growing program evaluation literature provides evidence that NREGS has had a large impact on rural poverty in India, ${ }^{33}$ which is a central factor in the Maoist insurgency.

The Maoist insurgency is spatially concentrated in India's poorest regions, ${ }^{34}$ with a history of

\footnotetext{
${ }^{30}$ Grossman, 1991; Collier and Hoeffler, 2004; Gurr, 1970; Sambanis, 2001

${ }^{31}$ Grossman, 1991; Collier and Hoeffler, 2004; Gurr, 1970; Sambanis, 2001

${ }^{32}$ Dutta et al., 2012

${ }^{33}$ Imbert and Papp, 2015; Berg et al., 2012

${ }^{34}$ Borooah, 2008; Gawande, Kapur and Satyanath, 2015; Eynde, 2011; Gomes, 2015
} 
underdevelopment and political marginalization dating to the colonial era. ${ }^{35}$ Poverty-related grievances are central to the Maoist insurgency's ideological appeal. ${ }^{36}$ The Maoist insurgency can be traced historically to the "Naxalite" movement, which originated in 1967 as an antilandlord peasant uprising in Naxalbari, a village in West Bengal. ${ }^{3738}$ The insurgency subscribes to a left-wing Maoist ideology and advocates pro-rural poor agenda, including land redistribution and the prevention of displacement of tribal populations by mining projects.

The roll-out of NREGS also provides a valuable setting to evaluate our contention that the pacifying effects of anti-poverty programs depend upon state capacity, which varies widely across the districts in the six 'red belt' states under study. ${ }^{39}$ The implementation of NREGS depends upon local state capacity because it is administered locally by elected village councils and bureaucrats at the district level (the rough equivalent of a US county). The program is also complex to administer, intensifying the importance of local bureaucratic capabilities in shaping local household access to the program. ${ }^{40}$ Though by law NREGS guarantees households as much employment as desired (up to the 100 day limit), due to weak state capacity in practice "rationing", or under-provision of employment relative to demand, is rampant. ${ }^{41}$

Two of the states under analysis, Andhra Pradesh and Chhattisgarh, have disciplined bureaucracies and an established track record of successful administration of government programs. According to the 2009 national sample survey, just $24.9 \%$ and $30.6 \%$ of households in Andhra Pradesh and Chhattisgarh, respectively, were rationed (wanted NREGS unemployment but did

\footnotetext{
${ }^{35}$ Mukherjee, 2013; Verghese and Teitelbaum, 2011

${ }^{36}$ Bhatia, 2005; Harriss, 2010; Guha, 2007

${ }^{37}$ Banerjee, 1980

${ }^{38}$ Though the Naxalite movement in West Bengal was violently repressed, the movement survived over the next three decades in the form of splinter groups. The Maoist insurgency resurged in the 2000s, in particular after 2004, when the two major Maoist movement factions joined forces to form the Communist Party of India (Maoist) (see Chakravarti (2009) and Pandita (2011)).

${ }^{39}$ Pritchett, 2009; Kapur and Mehta, 2007

${ }^{40}$ Implementing NREGS requires local elected leaders and bureaucrats to gauge demand for employment, plan local works projects to meet demand, to submit plans for these projects in order to obtain funding from the state, and then to implement these projects and distribute employment and wages to individual households.

${ }^{41}$ Dutta et al., 2012
} 
not obtain it). In the remaining states, however, implementation of NREGS is poor, particularly in Bihar, Jharkhand, and Orissa, where bureaucratic effectiveness is dismal. ${ }^{42}$ NREGS rationing rates in these states were a staggering $78.5 \%, 62.8 \%$, and $56.7 \%$, respectively. Even within states, some districts are characterized by much weaker state capacity than others, a pattern resembling the presence of sub-national "brown areas" in developing countries more generally. ${ }^{43}$

In sum, in areas of adequate state capacity, NREGS plausibly provided benefits to local populations in a way that dis-incentivizes participation in the insurgency, bolsters the legitimacy of the Indian state vis-a-vis the Maoist insurgency, and addresses the roots of the Maoist conflict. In areas of low state capacity, however, such effects are less plausible. In the following sections we discuss the data and empirical strategy we utilize to evaluate the impact of NREGS on Maoist conflict violence.

\section{Data and Empirical Strategy}

\section{Measuring Violence}

Our outcome variable is Maoist conflict violence, measured in terms of violent incidents and deaths. One of the challenges of studying a rural insurgency is that violence is difficult to measure and easily available data sources are affected by severe reporting bias. To deal with these challenges, we assemble a new district-level panel data set on Maoist conflict violence from multiple press sources, including those in the local languages spoken in the regions impacted by the Maoist insurgency (Bengali, Hindi, Oriya, and Telugu). The data set covers 144 districts between 1999 and 2009 in the so-called "red corridor", the six central and eastern states - Andhra Pradesh, Bihar, Chhattisgarh, Jharkhand, Orissa, and West Bengal - in which over 90\% of Maoist conflict deaths occur. The data set geo-codes attacks and civilian, Maoist, and security force

\footnotetext{
${ }^{42}$ Imbert and Papp, 2011; Niehaus and Sukhtankar, 2013

${ }^{43}$ O’Donnell, 1999
} 
deaths to districts on a quarter-yearly basis. ${ }^{44}$ The six states together contain 144 districts and over 378 million people.

This local language data set, which took a team of local language researchers over two years to compile, alleviates significant under-reporting as well as urban and temporal reporting bias in other widely used data sets on the Maoist conflict based on English language new sources. This more accurate data set is important for our empirical strategy, which examines over-time variation in violence arising from an overwhelmingly rural insurgency. In Section 1 of the Online Appendix, we provide an in-depth description of how the data set was constructed, a validation against qualitative measures of conflict intensity, ${ }^{45}$ and a comparison against the widely used South Asia Terrorism Portal (SATP) database based on English language news sources. In brief, we capture $37 \%$ greater number of violent incidents and deaths than does the SATP database, especially in rural districts and in earlier years. We provide evidence that relying upon the biased SATP database, as two concurrent papers on the Maoist conflict do,(Fetzer, 2014; Khanna and Zimmermann, 2014) would, predictably, bias our estimates downward. This comparison is fruitful in highlighting the methodological importance of using local language data sources to study rural civil conflict accurately.

Figure 1 displays a map of total deaths and incidents associated with the Maoist conflict over time. Notably, violence spiked following the unification of two rival Maoist factions in 2004, an event which is widely viewed to have precipitated the resurgence of the Maoist conflict in India over the last decade. Violence falls steeply between 2006 and 2008, the period during which NREGS was rolled out. Though our data set ends in 2009, qualitative information suggests that in 2010 violence rose again, mainly due to the launch of 'Operation Green Hunt', a large-scale military offensive by the central government, before again declining gradually to pre-2004 levels between 2011 and 2015. Figure 2 displays a map of average annual deaths associated with the

\footnotetext{
${ }^{44}$ Because some districts split over the time frame under analysis, we aggregate data to the level of 2001 census district boundaries.

${ }^{45}$ Weinstein, 2006; Kalyvas, 2006
} 
Maoist conflict between 1999 and 2009 by district. Consistent with qualitative information, we see that within India's 'red corridor' Maoist conflict violence is centered around two 'hot-spots', one along the southern border between Andhra Pradesh and Chhattisgarh and the other around the northern border between Jharkhand and Bihar.

\section{Empirical Strategy and Explanatory Variable}

To estimate the effects of NREGS adoption on Maoist conflict violence, we take a difference in differences identification strategy. We exploit the staggered roll-out of NREGS across the 144 districts in our sample over three years between 2006 and 2008 in three distinct phases. Phase 1 districts received the program in February 2006, Phase 2 districts in April 2007, and Phase 3 districts in April 2008 (see Fig. 3). ${ }^{46}$ This provides a substantial amount of variation in exposure to the program, a "natural experiment" which we exploit to estimate its effects. For instance, we observe a full eight quarter-years of NREGS adoption in Phase 1 districts before Phase 3 districts received the program, and a full four quarters of program adoption before Phase 2 districts received the program.

All analyses include district and year fixed effects, which means that we identify the effects of NREGS adoption from changes in violence in districts receiving the program compared to changes in violence in districts experiencing no change in their program adoption status. District fixed effects absorb any time-invariant omitted variables that could bias the estimates. Time fixed effects absorb common time trends and shocks that impact the dynamics of conflict violence. Our core explanatory variable pools across the three different phases of NREGS adoption with a binary treatment indicator that takes a value of 1 following program adoption in a district and 0 otherwise, as is common in any fixed effects regression analysis (see e.g. Angrist and Pischke for a discussion) ${ }^{47}$.

\footnotetext{
${ }^{46}$ Three completely urban districts in the states under analysis, Hyderabad, Vishakhapatnam, and Kolkata, were not eligible to receive the program. These districts drop out from the analysis.

${ }^{47}$ Angrist and Pischke, 2008
} 
Figure 1: Maoist Conflict Violence Over Time, 1999-2009

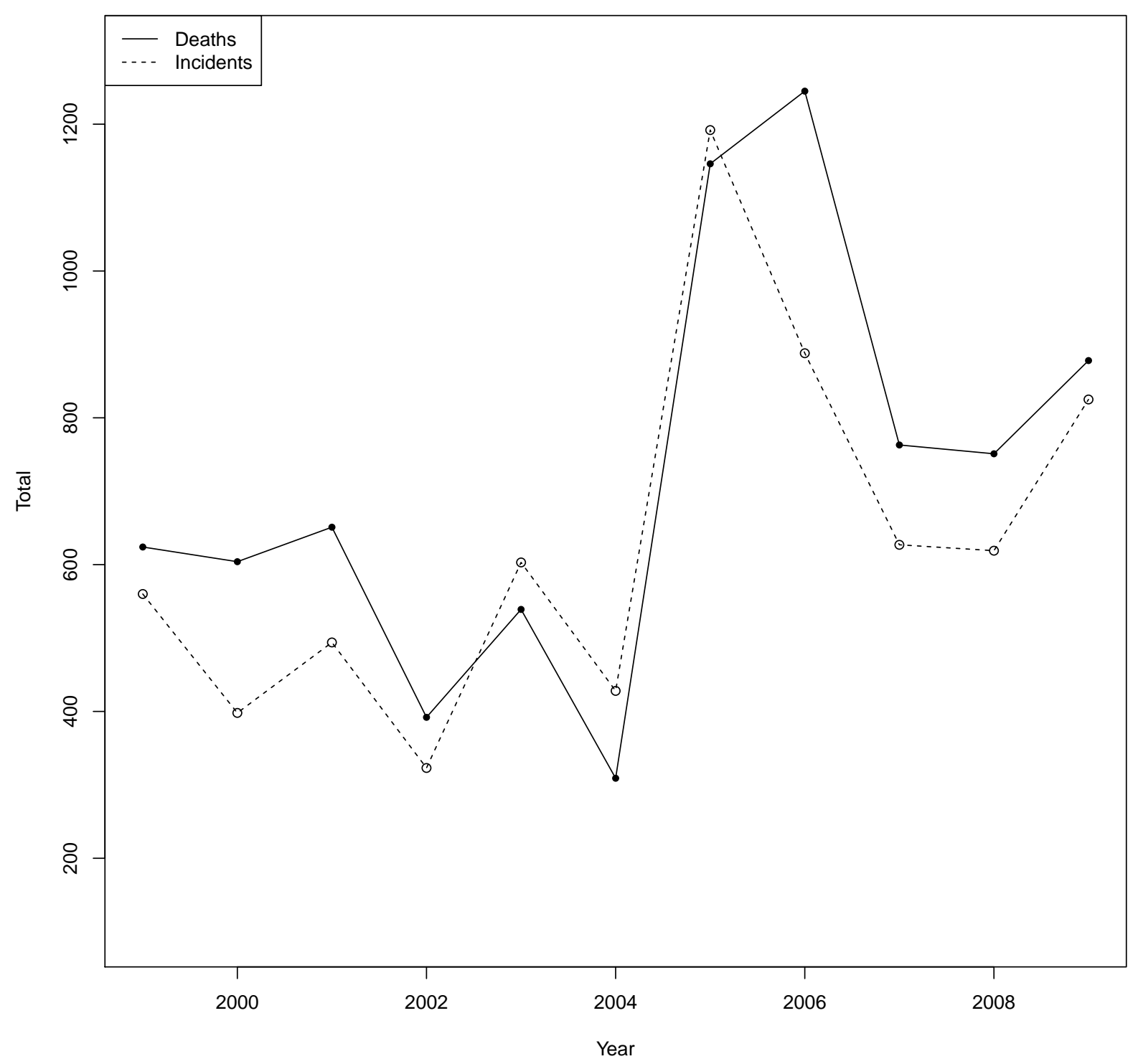

Notes: Incidents represents sum of recorded violent incidents, including those not resulting in deaths. Deaths sums civilian, Maoist, and security personnel deaths. Data set covers 144 districts in 'red belt' states - Andhra Pradesh, Bihar, Chhattisgarh, Jharkhand, Orissa, and West Bengal - between 1999 and 2009. 
Figure 2: Average Annual Deaths from Maoist Conflict by District, 1999-2009

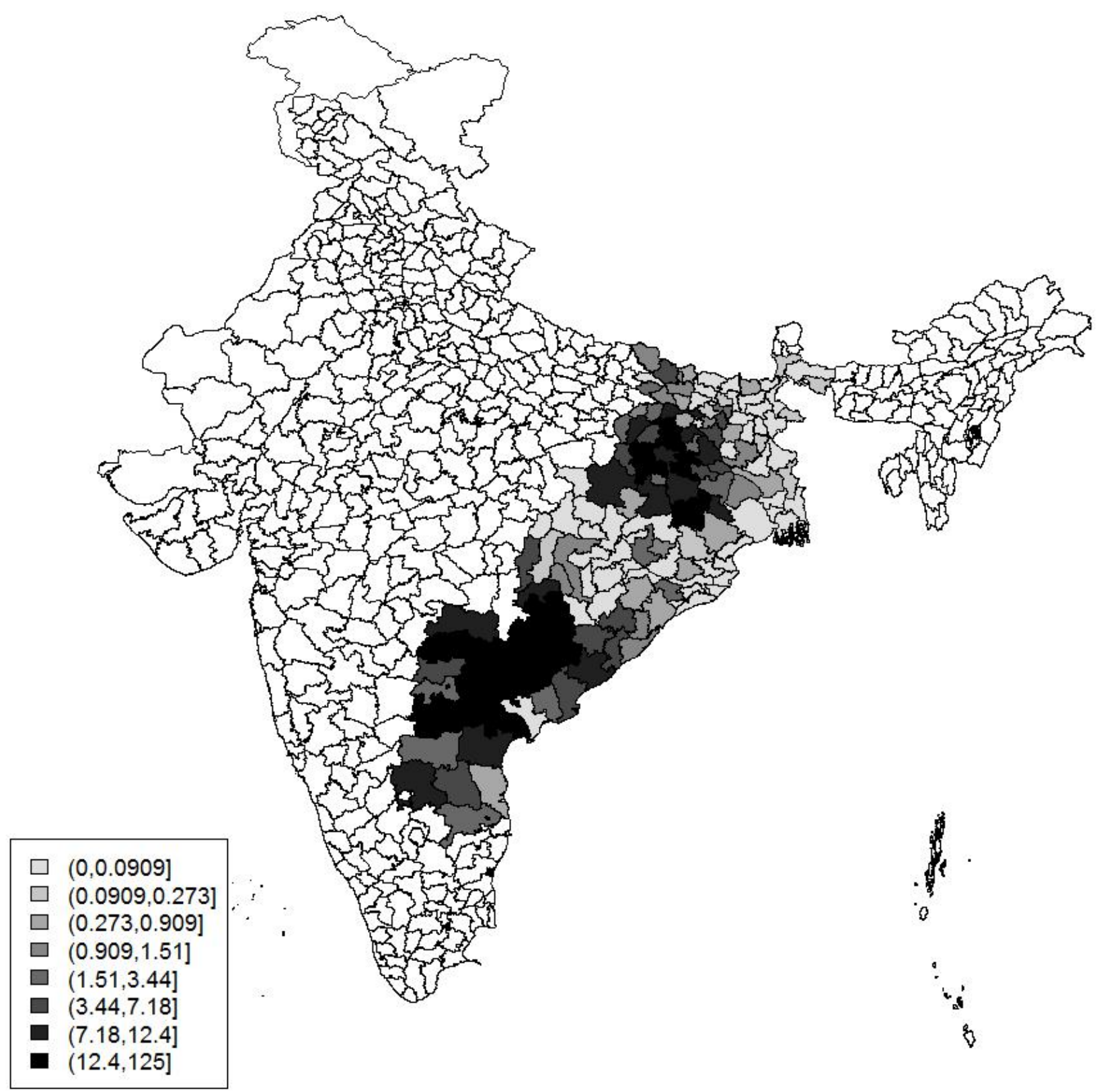

Notes: Districts shaded by decile of average annual number of total deaths resulting from Maoist conflict, 19992009. Data set covers 144 districts in 'red belt' states - Andhra Pradesh, Bihar, Chhattisgarh, Jharkhand, Orissa, and West Bengal - between 1999 and 2009. Unshaded districts not in analysis. 
Figure 3: Districts by NREGS Adoption Phase

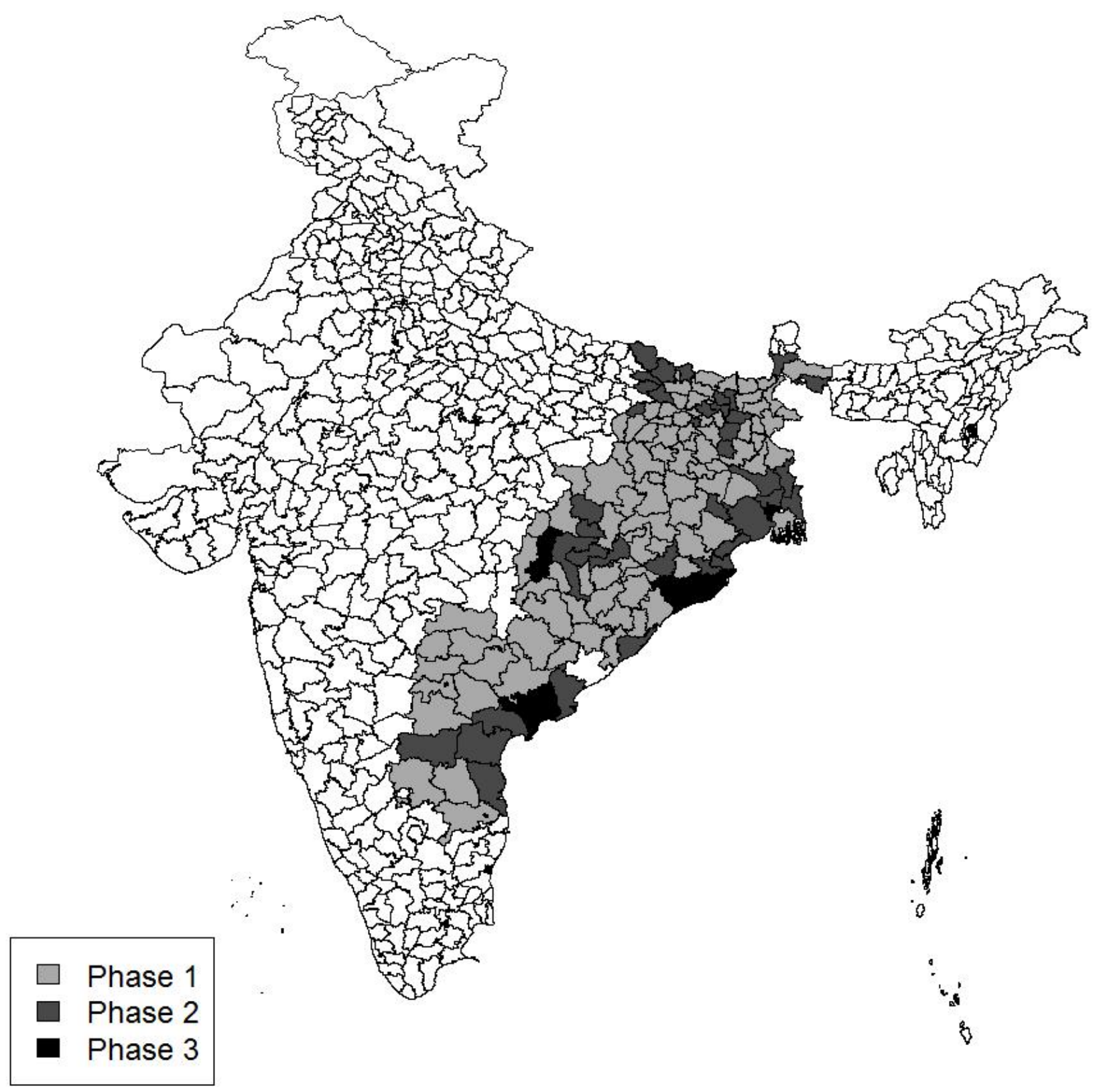

Notes: Districts shaded by NREGS adoption phase. Phase 1 districts received NREGS in 2006, phase 2 districts in 2007, and phase 3 districts in 2008. Unshaded districts not in analysis. 
An important challenge for our identification strategy is that districts were assigned to NREGS implementation phases non-randomly, raising concerns about the parallel trends assumption that underpins a difference in difference identification strategy. Districts were scored on a 'backwardness index' (BI), a score constructed by India's Planning Commission prior to the enactment of NREGS. ${ }^{4849}$ A fixed number of slots for each NREGS adoption phase was assigned by the Planning Commission to states. Within states, poorer districts were recommended to earlier phases of NREGS adoption in order of their rank on the backwardness index. However, thirty two districts were prioritized for phase 1 adoption regardless of score due to being classified as "left wing extremism affected" (LWE) by the Indian government. Additionally, states retained some discretion in the allocation of districts to NREGS adoption phases.

We deal directly with this issue by explicitly controlling for a district's backwardness index score and LWE classification in interaction with time dummy variables in all specifications. ${ }^{50}$ By conditioning for selection on observables, this absorbs time trends specific to LWE districts and time trends in violence related to development levels as measured on the backwardness index. We will later provide direct evidence on the validity of the parallel trends assumption by testing for pre-NREGS adoption trends in violence. In Table 1, we provide preliminary cross-sectional evidence that controlling for a district's BI score and LWE designation achieves balance across phases on major pre-treatment variables plausibly related to the the Maoist conflict.

Predictably, Phase 1 districts are characterized by lower real wages, higher disadvantaged minority population shares and higher pre-treatment violence levels. As discussed, poorer and more violence-prone districts were prioritized by the Indian government for earlier phases of

\footnotetext{
${ }^{48}$ Nayyar, 2003

${ }^{49} \mathrm{~A}$ district's composite score was based upon percentage of disadvantaged minorities (scheduled caste and tribal groups) in the population (M), agricultural output per worker $(\mathrm{O})$, and agricultural wage rate (W), measured with census and sample survey data from the 1990s. The formula used to compute a district's BI score was: $B I_{i}=\frac{\max (M)-M_{i}}{\max (M)-\min (M)}+\frac{O_{i}-\min (O)}{\max (O)-\min (O)}+\frac{W_{i}-\min (W)}{\max (W)-\min (W)}$

${ }^{50}$ Five predominantly urban districts, Patna, Raipur, Dhanbad, Ranchi, and Howrah, in the states under analysis did not receive a score on the backwardness index. We construct a score for each of these districts by averaging the backwardness index scores of neighbouring districts. All results are also robust to simply dropping these districts from the analysis.
} 


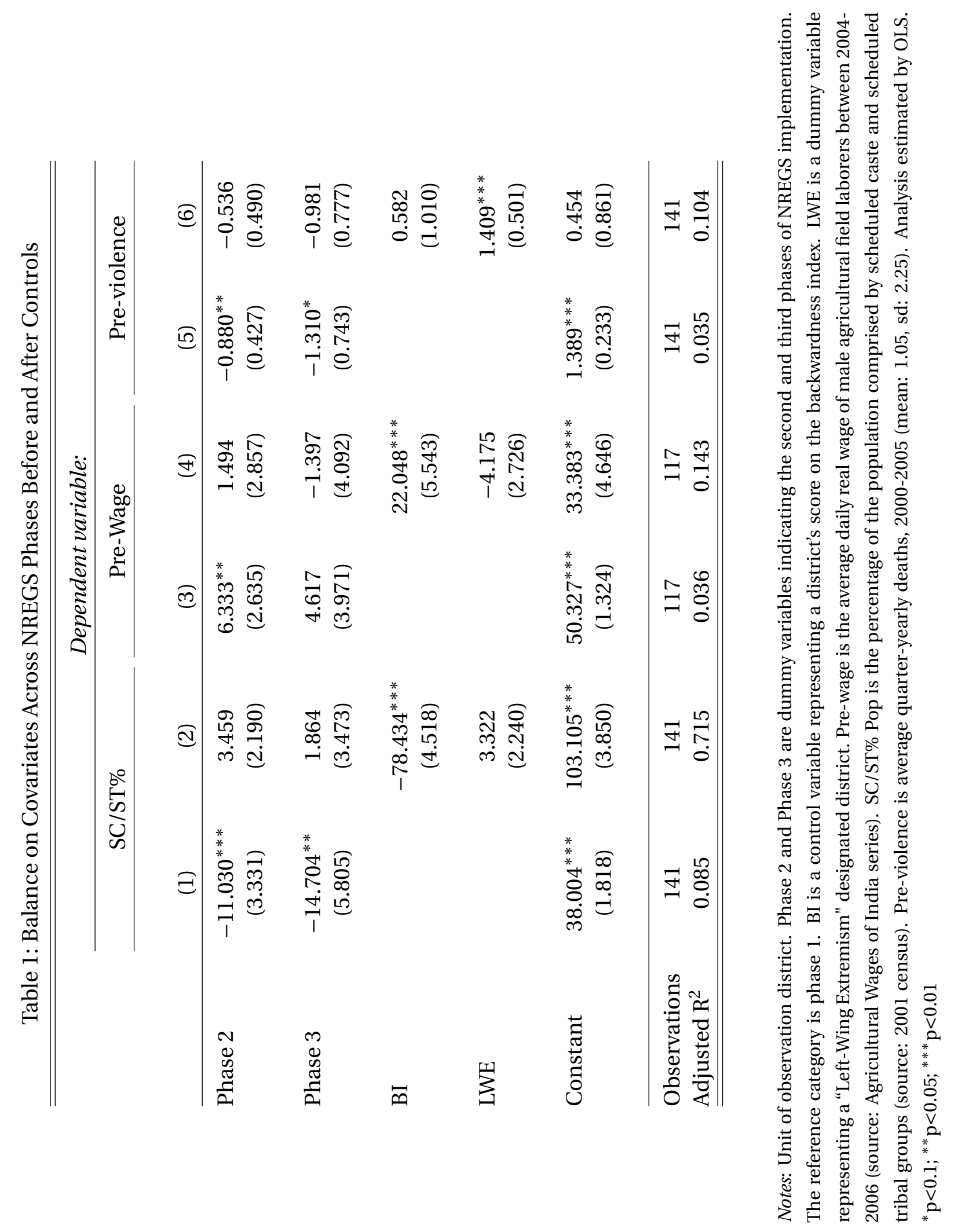


NREGS adoption. After controlling for BI score and LWE classification used to assign districts to phases of NREGS implementation in this way, however, the different phase groups are no longer statistically distinguishable in terms of these pre-treatment covariates. These results highlight the importance of conditioning upon BI score and LWE classification (in interaction with time dummy variables) in our empirical strategy, to ensure that our analyses estimate the effects of NREGS adoption and not time trends related to omitted variables.

\section{State Capacity and Other Variables}

An important part of our empirical investigation is to study how the effects of NREGS adoption vary as a function of local state capacity. State capacity, which refers to the latent capacity of a government to implement its policy objectives as distinct from a political commitment to specific policy choices, ${ }^{51}$ is notoriously difficult to measure; existing literature typically relies on a number of proxies, ranging from per capita income levels, to measures of taxation, to various expert perception-based indices. ${ }^{52}$

Because we utilize within-country micro-level data, we are in a position to develop more precise measures of state capacity at the local level. We utilize two measures of local state capacity at the district level. The first is a measure of program intensity based on average NREGS annual employment provision per capita. This is computed by taking administrative data from the Ministry of Rural Development on average annual person-days of employment for each district and normalizing by the rural population as measured in the 2001 census. Given the prevalence of "rationing" of employment under NREGS due to weak bureaucratic capacity, as discussed, the amount of employment provided per person is a good direct measure of variation in local capacity to implement the program. However, employment provision is potentially also driven by other variables, such as political commitment to NREGA, or pre-existing violence, which we

\footnotetext{
${ }^{51}$ Fukuyama, 2004; Skocpol, 1985

${ }^{52}$ Hendrix, 2010
} 
would wish to exclude from a measure of state capacity. An econometric solution that we take is to control for these potential omitted variables. But it is also possible to develop a second more direct measure of local state capacity that is measured prior to and independent of the performance of NREGS.

To measure pre-existing district-level state capacity, we construct a composite ranking of districts based on average village-level access to four extremely basic state services as measured by enumerators in the 2001 census. The four basic state services we measure for each district are share of villages with: i) a paved road; ii) a primary school; iii) a primary health center; iv) and an agricultural credit cooperative (the lowest tier of the Indian government's agricultural credit network). Each of the 144 districts in our sample is ranked on each of these indicators, and these ranks are averaged to construct a composite ranking of local state capacity measured several prior years to the enactment of the program under study. This ranking of local state capacity captures some of the essential ingredients of state capacity as a concept. It captures a district's ability to implement policies, measured prior to and independent of the specific program under study. ${ }^{53}$ It is 'sticky' over time, ${ }^{54}$ and succeeds in predicting actual NREGS employment provision nearly a decade later. The top quartile of districts on this indicator of local state capacity provided on average 4.2 days of NREGS employment per capita, the second quartile provided 3.5 days per capita, the third quartile 2.5 days per capita, and the bottom quartile 2.5 days per capita. Section 2 of the Online Appendix provides a detailed discussion and analysis of our two measures of local state capacity.

Additionally, some analyses investigate variation in the effects of NREGS as a function of rainfall shocks. Annual district-level rainfall data in total millimeters comes from the Indian Meteorological Department, which creates monthly gridded rainfall maps based on rainfall gauges throughout the country. We take the natural log of this variable so that rainfall is mea-

\footnotetext{
${ }^{53}$ Fukuyama, 2004

${ }^{54}$ Acemoglu, García-Jimeno and Robinson, 2015
} 
sured in $\mathrm{ln} \mathrm{mm}$. Since all regressions include district fixed effects, they implicitly identify the effects of over time variation within districts i.e. rainfall shocks. For the first two quarters in a year, we define the salient rainfall realization as that of the previous year (the monsoon rainfall occurs during the summer months), while for the latter two quarters in the year we define the salient rainfall realization as that of the current year.

Table 2 reports descriptive statistics for the major variables in the analysis. We note considerable within-district variation over time in violence. Our empirical analysis will explore the role that NREGS adoption has played in impacting this variation over time within districts. 


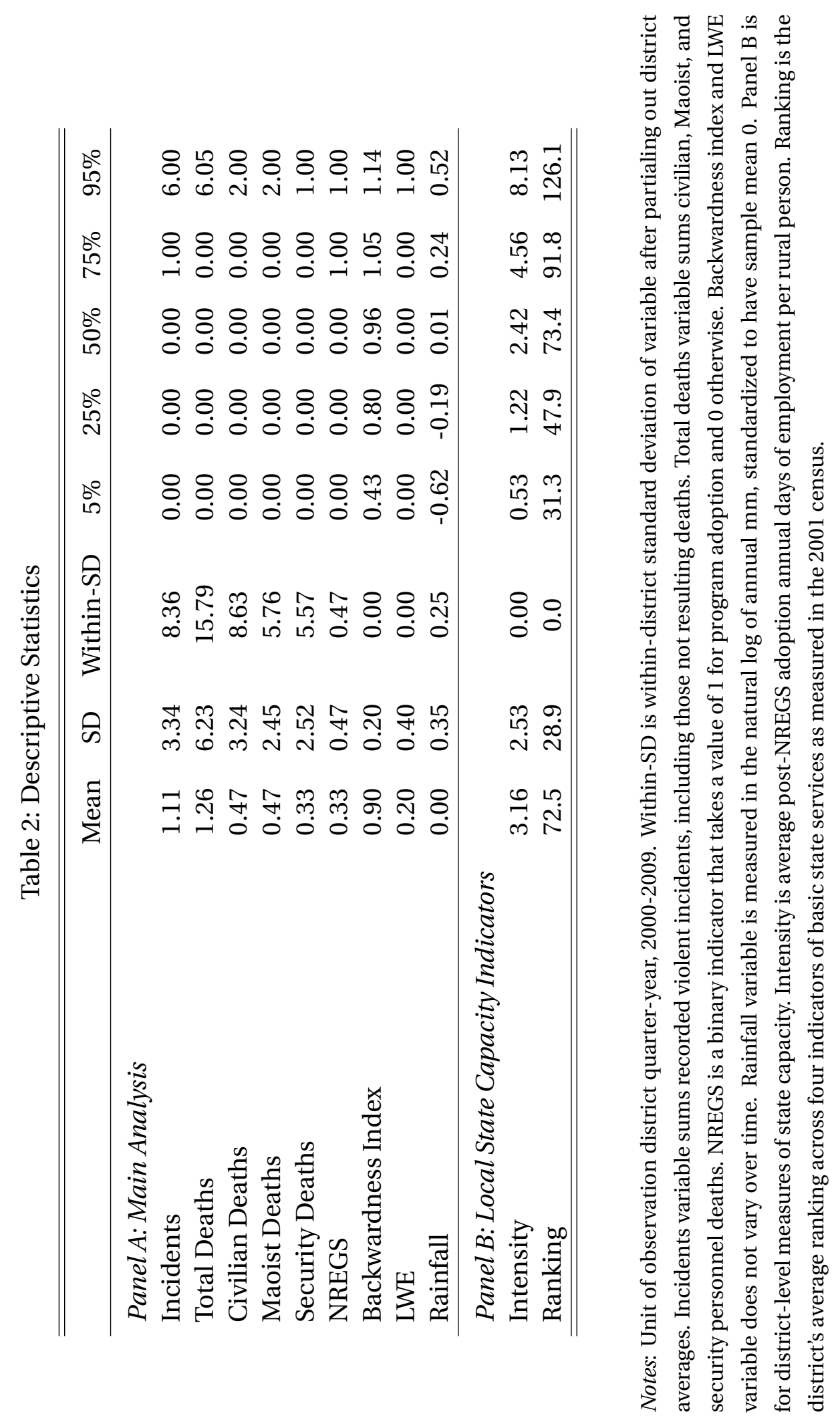




\section{Results}

To estimate the effects of NREGS adoption, as discussed, we utilize a difference in differences identification strategy based upon the phased roll-out of NREGS across districts between 2006 and 2008. We utilize a Poisson quasi-maximum likelihood (QML) regression model, which is appropriate for our violence outcome data - a count variable. ${ }^{55}$ We estimate a regression equation of the form,

$$
\mathbb{E}\left(\text { Violence }_{i t}\right)=\exp \left(\gamma_{i}+\tau_{t}+\beta_{1} N R E G S_{i t}+\delta \mathbf{X}^{\prime}\right)
$$

where Violence $_{i t}$ is either total incidents or total deaths in district $i$ and quarter-year $t$, either total incidents or total deaths. The variable $N R E G S_{i t}$ is an indicator variable for NREGS adoption, pooling across all three phases of NREGS adoption. To compute the effect of NREGS adoption on the rate of Maoist conflict violence, our substantive quantity of interest, we exponentiate the coefficient on the treatment indicator (which gives the incidence rate ratio), and subtract one to obtain the estimated percentage change in violence caused by NREGS adoption. To account for over-time correlation within districts in violence, all models estimate robust standard errors adjusted for clustering within districts.

All regressions include district fixed effects, $\gamma_{i}$. This means we utilize within-district variation over time to estimate NREGS's effects on violence and can rule out important time-invariant omitted variables, such as terrain and ethnic composition, which might impact violence. All regressions include year fixed effects, $\tau_{t}$, which absorb time-based shocks and trends common to all districts. The term $\mathbf{X}^{\prime}$ is a vector of covariates, which will be discussed in detail along with the results. As discussed, all regressions control for a district's score on the backwardness index

\footnotetext{
${ }^{55}$ The Poisson QML model yields coefficient estimates that are robust to arbitrary distributional assumptions as long as the conditional mean is specified correctly. ${ }^{56}$ The Poisson model is also a consistent estimator in the the presence of unit fixed effects, unlike other count models, which suffer from the 'incidental parameters' problem. Reported estimates are substantively close to estimates from OLS, negative binomial regression models, as well as zero-inflated count models.
} 
as well as LWE classification, in interaction with year dummy variables. These eliminate or at least minimize concerns about non-parallel time trends across different phase groups arising from the assignment of poorer and more violence-prone districts to earlier phases of NREGS adoption on the basis of these official indices. In support of this, we will directly test and provide evidence on the parallel trends assumption that underpins our difference-in-differences empirical strategy.

Table 3 reports the main regression estimates. The table reports both the coefficient estimates with their standard errors as well as the substantive quantity of interest, the estimated percentage change in violence caused by NREGS adoption. The regression estimates suggest that NREGS adoption caused a significant reduction in violence. In the base specification reported in columns (1) and (6), NREGS adoption is estimated to have caused a $57 \%$ reduction in Maoist conflict incidents and a 63\% reduction in Maoist conflict deaths. Though the estimates of the program's effects on total deaths do not reach conventional levels of statistical significance, the coefficients are substantively important, large and stable across specifications. The main reason that the the standard errors are larger for models of total deaths than for models of total incidents is that the variance for total deaths as a variable is much larger.

The estimates are stable across an array of additional specifications which seek to address different concerns. The specifications reported in columns (2) and (7) include a (one quarteryear) lagged explanatory variable indicator to explore the time path of NREGS's effects. The negative and significant coefficient on the lagged treatment indicator suggests that a large part of NREGS's violence-reducing effects emerged in the long run, a pattern which we explore in greater depth in the next section. Columns (3) and (8) control for a lagged value of the dependent variable, to account for possible auto-correlation dynamics in violence. Columns (4) and (9) control for a spatial lag of the explanatory variable, defined as the share of spatially contiguous districts adopting NREGS. We include this variable to control for potential spatial spillover effects, (Staniland, 2014; Cederman and Gleditsch, 2009) in particular to deal with the 


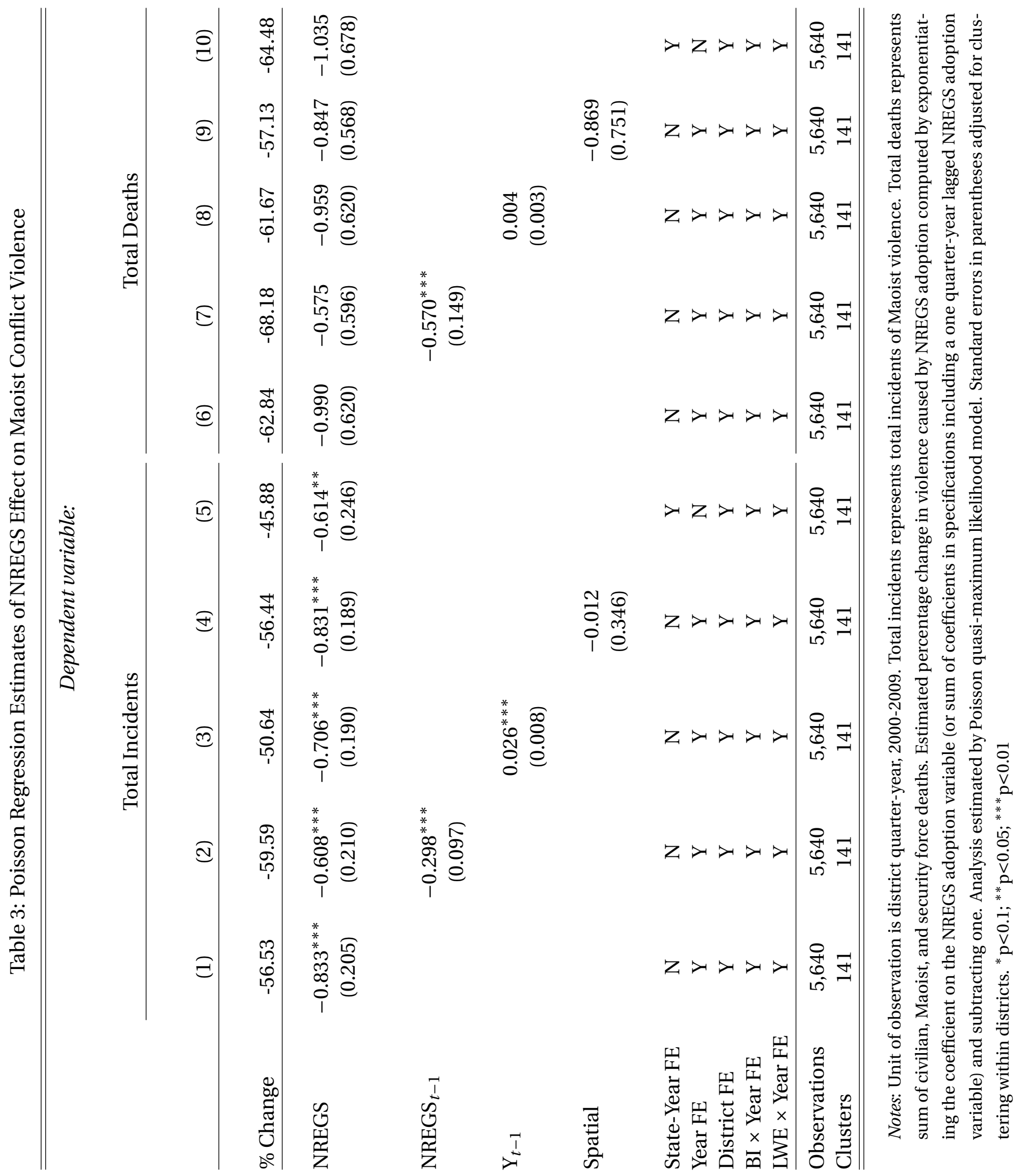


possibility that NREGS adoption may have reduced violence in a district by simply displacing it to neighboring districts, a phenomenon that has been found in other contexts.(Dube, Dube and García-Ponce, 2013) We find no evidence for this in the case of NREGS, however. Finally, columns (5) and (10) control for state-year fixed effects, which rules out the possibility that non-parallel trends across states, or any state-level policies such as counter-insurgency police campaigns, drive the results. The estimates are substantively unchanged across specifications; we report additional robustness tests in Section 3 of the Online Appendix.

The estimates suggest that the roll-out of NREGS has played a large role in mitigating Maoist conflict violence, and that in the program's absence levels of violence might have been much higher. To provide a back of the envelope calculation of the size of these pacifying effects, consider the total levels of violence observed in 2008: 619 violent incidents resulting in 751 deaths. According to our regression estimates, counter-factually absent the adoption of NREGS across districts, levels of total violence would have been 1440 violent incidents resulting in 2030 deaths — suggesting that the program eliminated roughly 821 potential violent incidents and 1279 casualties across districts in that year. While these are counter-factual projections based on our estimates, they demonstrate that NREGS played an important role in the overall pacification of the conflict between 2006 and 2008 and vindicate the Indian government's strategy of combating the insurgency through development programs, the largest of which is NREGS.

More broadly, the estimates are among the largest to date in the comparative literature on the impact of development programs on conflict. To place these effects in comparative perspective, we investigate the financial scale of the program. In 2008, total program cost was roughly $\$ 1.77$ billion across the districts in our sample, according to administrative data $-\$ 8.3$ per rural capita, or $\$ 142$ per participating household (using a population-weighted 28\% rural household NREGS participation rate from the 2009 national sample survey for the states under analysis and average household size of 4.8 from the 2007 national family health survey as estimates). These are very sizable expenditures. The $\$ 142$ of expenditure per participating house- 
hold amounts to roughly 84 days of wages for a male agricultural laborer (based on the average daily wage, $\$ 1.7$, for male agricultural laborers in 2008 in our sample, according to the Agricultural Wages of India data series) - which could very plausibly shift participating households economic' incentives to participate in rebellion or mitigate grievances with the state. None of the previously studied programs in the literature on development programs and conflict provide expenditures on local populations on the same scale relative to local incomes as NREGS, helping to explain the large pacifying effects we observe.

\section{State Capacity}

As discussed, however, NREGS's violence reducing effects plausibly depended heavily on preexisting local state capacity. Not only were the expenditures described above concentrated in districts with sufficient local state capacity to build projects and implement the program, but in these areas a larger share of expenditures was likely to pass through though to local populations in the form of genuine employment provision as opposed to corruption.

To test for these heterogeneous effects, we estimate regressions which interact the main explanatory variable, NREGS adoption, with i) a district-level indicator of program intensity based on average annual NREGS employment provision per capita and ii) a direct ranking of local state capacity based on district-level access to basic state services as measured in the 2001 census. We divide the ranking variable into quartiles for ease of interpretation, with the bottom quartile serving as the reference category. The level or direct effects of state capacity are absorbed by district fixed effects. To rule out the concern that heterogeneous effects are driven not by state capacity but other underlying differences, we also control for several pre-treatment socioeconomic variables as well pre-treatment violence in interaction with the NREGS adoption variable. These control variables are centered at their means, so that the lower order NREGS adoption term and the NREGS adoption term interacted with local state capacity can be interpreted independently. The results are reported in Table 4. 
Table 4: State Capacity and the Heterogeneous Effects of NREGS on Violence

\begin{tabular}{|c|c|c|c|c|}
\hline & \multicolumn{4}{|c|}{ Dependent variable: } \\
\hline & \multicolumn{2}{|c|}{ Total Incidents } & \multicolumn{2}{|c|}{ Total Deaths } \\
\hline & $(1)$ & $(2)$ & $(3)$ & $(4)$ \\
\hline NREGS & $\begin{array}{c}0.370 \\
(0.354)\end{array}$ & $\begin{array}{c}0.479 \\
(0.372)\end{array}$ & $\begin{array}{l}-0.623 \\
(0.841)\end{array}$ & $\begin{array}{l}-0.202 \\
(0.822)\end{array}$ \\
\hline NREGS $\times$ Intensity & $\begin{array}{c}-0.238^{* * *} \\
(0.061)\end{array}$ & & $\begin{array}{l}-0.022 \\
(0.082)\end{array}$ & \\
\hline NREGS×Top Quartile Ranking & & $\begin{array}{c}-1.166^{* * *} \\
(0.198)\end{array}$ & & $\begin{array}{c}-0.728^{* * *} \\
(0.266)\end{array}$ \\
\hline NREGS $\times$ Second Quartile Ranking & & $\begin{array}{c}-0.917^{* * *} \\
(0.302)\end{array}$ & & $\begin{array}{l}-0.292 \\
(0.437)\end{array}$ \\
\hline NREGS×Third Quartile Ranking & & $\begin{array}{l}-0.225 \\
(0.336)\end{array}$ & & $\begin{array}{l}-0.349 \\
(0.399)\end{array}$ \\
\hline Year FE & $\mathrm{Y}$ & $\mathrm{Y}$ & $\mathrm{Y}$ & $\mathrm{Y}$ \\
\hline District FE & $\mathrm{Y}$ & $\mathrm{Y}$ & $\mathrm{Y}$ & $\mathrm{Y}$ \\
\hline $\mathrm{BI} \times$ Year FE & $\mathrm{Y}$ & $\mathrm{Y}$ & $\mathrm{Y}$ & $\mathrm{Y}$ \\
\hline $\mathrm{LWE} \times$ Year FE & $\mathrm{Y}$ & $\mathrm{Y}$ & $\mathrm{Y}$ & $\mathrm{Y}$ \\
\hline Interacted Controls & $\mathrm{Y}$ & $\mathrm{Y}$ & $\mathrm{Y}$ & $\mathrm{Y}$ \\
\hline Observations & 4,680 & 4,680 & 4,680 & 4,680 \\
\hline Clusters & 117 & 117 & 117 & 117 \\
\hline
\end{tabular}

Notes: Unit of observation is district-quarter year, 2000-2009. Total incidents represents total incidents of Maoist violence. Total deaths represents sum of civilian, Maoist, and security force deaths. Intensity is a district-level measure of average NREGS employment per rural capita. Top, Second, and Third quartile are indicators for quartiles on a district-level ranking of state capacity based on access to basic state services as measured in the 2001 census; the bottom quartile is the reference category. All analyses control for pre-existing wage level, pre-existing levels of violence, pre-existing irrigation level, and pre-existing share of scheduled caste and tribe minorities in interaction with the NREGS adoption variable. Control variables are centered for ease of interpretation. Analysis estimated by Poisson quasi-maximum likelihood model. Standard errors in parentheses adjusted for clustering within districts. ${ }^{*} \mathrm{p}<0.1$; $^{* *} \mathrm{p}<0.05 ;{ }^{* * *} \mathrm{p}<0.01$ 
The results suggest that the violence reducing effects of NREGS adoption were overwhelmingly concentrated in states and districts which implemented the program effectively. Strikingly, once the NREGS adoption variable is interacted with measures of local state capacity, the lower order term is no longer significant and in fact slightly positive in some specifications suggesting that the heterogeneity is so large that in the lowest state capacity districts NREGS had essentially no impact on violence whatsoever. Controlling for a variety of other factors which may generate heterogeneous effects, the estimates suggest that in the top state capacity quartile of districts NREGS adoption reduced violent incidents by $50 \%$, whereas in the bottom state capacity quartile of districts the impact on violence is positive but statistically indistinguishable from zero. In the top state capacity quartile of districts, NREGS adoption is estimated to reduce total deaths by $61 \%$, whereas in the bottom quartile the effect is slightly negative and statistically indistinguishable from zero.

In interpreting these effects, it is important to keep in mind that by including district fixed effects, the regression analyses absorb static omitted variables, including the level effects of state capacity on violence. The estimates suggest that over time NREGS adoption caused a reduction in violence in districts with high levels of pre-existing local state capacity, whereas it did not do so in districts with low levels of pre-existing local state capacity. An important concern is that time trends in violence related to local state capacity might drive our results. We investigate this concern in Section 4 of the Online Appendix, looking at time trends in violence around the adoption of NREGS in high- and low-state capacity districts. The results suggest that in highstate capacity districts, violence fell following the adoption of NREGS and not prior, while in low-state capacity districts violence remained flat over time. This suggests that the interaction of high local state capacity and the adoption of the anti-poverty program drove the decline in violence, rather than either one on its own.

Consistent with the theoretical discussion, therefore, the findings show that the effects of anti-poverty programs on violent civil conflict depend heavily on state capacity. What are the 
comparative implications for development programs and their likely effects on civil conflict? In comparative perspective, India is thought to represent a case of "intermediate" state capacity. ${ }^{57}$ Within India, the violence reducing effects of NREGS were concentrated in the top two quartiles of local state capacity. In countries and sub-regions with intermediate to high levels of state capacity, therefore, large-scale anti-poverty programs may have significant pacifying effects. In countries and sub-regions with intermediate to low levels of state capacity, however, the prospects for anti-poverty programs to mitigate violent conflict are dimmer. Overall, the findings suggest that while development programs are no panacea for conflict, in intermediate to high state capacity settings they can play a significant role in reducing violence.

\section{Timing of Effects}

One concern in interpreting the results is that perhaps districts adopting NREGS were experiencing declining trends in violence relative to control districts, independent of program adoption — which would violate the 'parallel trends' assumption that underpins our empirical strategy. To address this concern, we investigate fine-grained time patterns of changes in violence before and after the adoption of NREGS. We regress our measures of violence on indicators for each of the eight quarters prior to NREGS adoption and for each of the eight quarters including and following NREGS adoption (the final dummy variable is an indicator of the eighth quarter onward). This analysis tests for any changes in violence before and after the adoption of NREGS on a time period-by-period basis, comparing districts experiencing a change in their program adoption status against districts experiencing no change in their program adoption status. As before, we include district and year fixed effects and controls for the backwardness index score and LWE classification in interaction with year dummy variables. We report the estimated coefficients in the form of a plot in Figure 4.

The analysis shows that the coefficient estimates on the pre-adoption quarter dummy vari-

\footnotetext{
${ }^{57}$ Evans, 1995; Kohli, 2004
} 
Figure 4: Changes in Violence Before and After NREGS Adoption by Quarter-Year

Outcome: Total Incidents

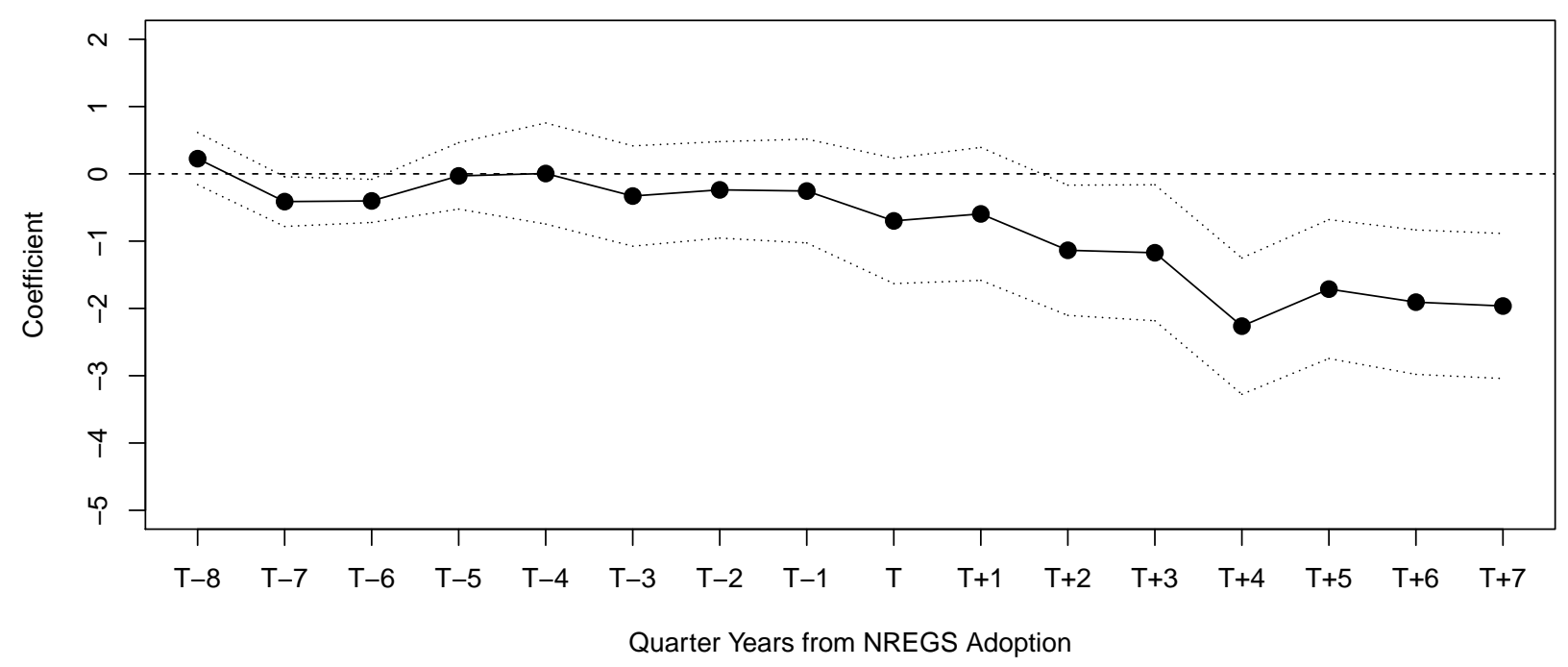

Outcome: Total Deaths

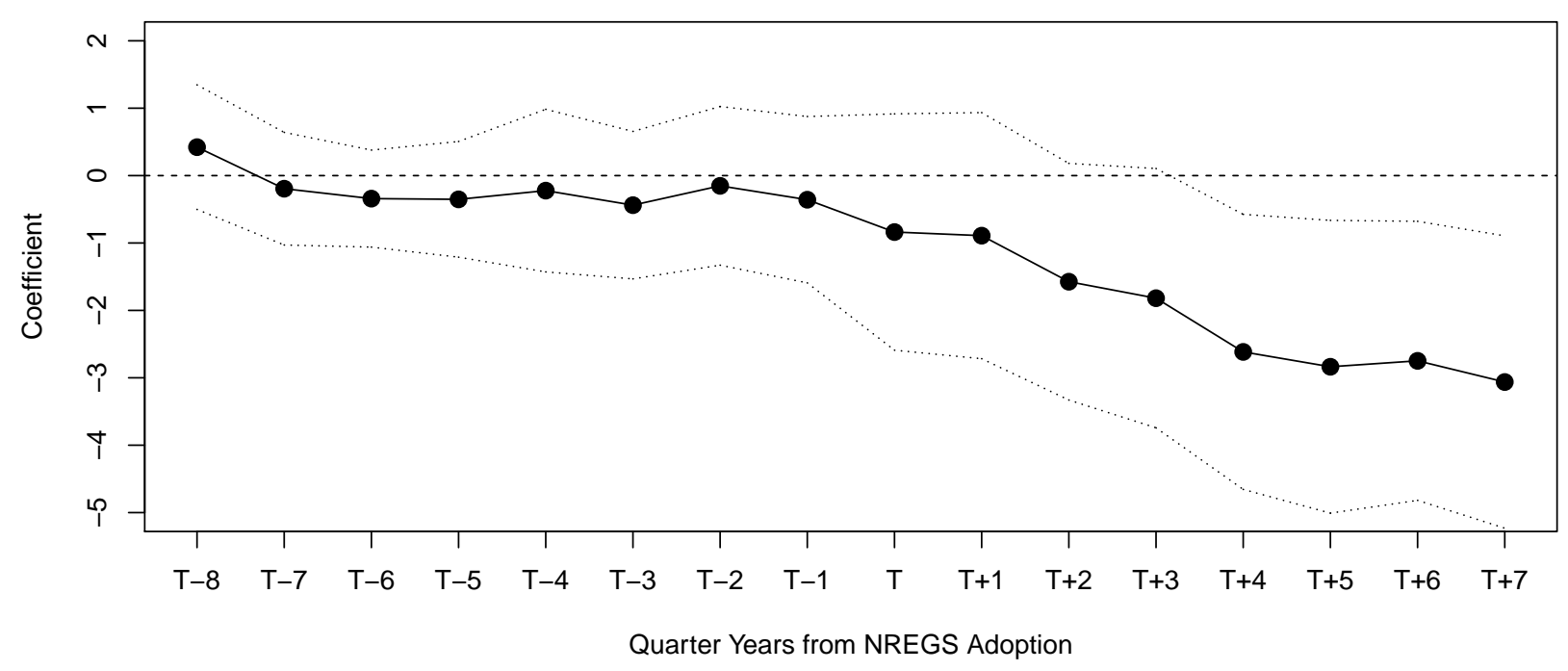

Notes: Unit of observation district-quarter year. Points represent coefficient on indicator of time period, relative to the adoption of NREGS at time T. Dashed bands represent 95\% confidence intervals. Final time period indicator represents the eighth quarter of program adoption onward. Poisson QML regression model controls for district and year fixed effects, and backwardness index score variable and LWE designation interacted with year dummy variables. Standard errors adjusted for clustering within districts. 
ables are stable and close to zero in the eight quarters in advance of NREGS adoption. This crucial "placebo" test provides evidence that our results are not driven by pre-adoption trends in violence. Instead, the analysis shows, both violent incidents and deaths started to fall precisely in the quarter in which NREGS was adopted, with the violence-reducing effects of the program emerging fully in the long run over a period of two years. The long-run nature of NREGS's pacifying effects is consistent with qualitative information about the gradual uptake of the program. The results are also realistic in showing that anti-poverty programs pacify longstanding civil conflict gradually, as opposed to immediately, .

A final concern that remains is that perhaps other interventions, whether counter-insurgency operations or other development programs, were specifically timed to coincide with the roll-out of NREGS across districts. We discuss and analyze this possibility systematically in Section 4 of the Online Appendix. In brief, there is little evidence that other major interventions were formally or informally 'bundled' with NREGS. There is no evidence of a short-run spike in Maoist and security force deaths around the adoption of NREGS, which would be typical of counterinsurgency operations. We provide evidence that state-level police numbers as well as roadbuilding under India's second largest rural development program were uncorrelated with the roll-out of NREGS. We also provide evidence that in high state-capacity localities, violence fell precisely following the adoption of NREGS and not prior - suggesting that it is the adoption of the anti-poverty program in high-state capacity settings which drives the pacifying effects we observe rather than secular changes in violence related to local state capacity on its own.

\section{Rainfall Shocks and the Income Channel}

In line with rebel opportunity cost and economic grievance theories, we have argued that NREGS adoption reduced violence by improving rural livelihoods — thereby undercutting popular support for insurgency and by reducing the economic incentives to participate in rebellion. As previous research notes, the mitigation of "greed" and "grievance" are distinct channels through 
which development programs may reduce violence. ${ }^{58}$ Both relate, however, to the improvement of rural livelihoods as the main driver of NREGS's pacifying effects - which we therefore jointly term an "income" channel in order to differentiate them from entirely separate categories of explanation.

An important implication of the income channel is that NREGS's violence-reducing should have been larger in districts experiencing a negative rainfall shock to agricultural productivity and labor demand. A large program evaluation literature shows that NREGS serves as a particularly important source of supplemental income to rural households during droughts. ${ }^{59}$ To examine whether the program's violence-reducing effects were correspondingly larger during these periods, we interact the NREGS adoption variable with a district-level measure of rainfall, a well known source of variation in agricultural productivity and labor demand in rural economies. ${ }^{60}$ Since we include district fixed effects, we implicitly identify the effects of within district rainfall variation over time, or rainfall shocks. An income channel-based theory would expect to see a positive estimate of the coefficient on the interaction term, implying that more negative rainfall realization results in a larger reduction in violence after the adoption of NREGS (or, conversely, a more positive rainfall realization results in a smaller reduction in violence). We report these analyses in Table 5.

The large, positive and statistically significant coefficient estimates on the interaction term between rainfall and NREGS adoption in columns (1) and (2) provide strong support for the idea that NREGS's violence reducing effects were larger in districts experiencing a negative rainfall shock. Relative to average levels of rainfall, a one within-district standard deviation (0.24) shortfall of rainfall is estimated to intensify NREGS's pacifying effects from a $50 \%$ to $64 \%$ reduction in violent incidents and from a $61 \%$ to $72 \%$ reduction in total deaths. This is consistent with an income channel because it shows that NREGS's pacifying effects are larger when the program

\footnotetext{
${ }^{58}$ Kalyvas, 2008

${ }^{59}$ Imbert and Papp, 2015

${ }^{60}$ Miguel, Satyanath and Sergenti, 2004
} 


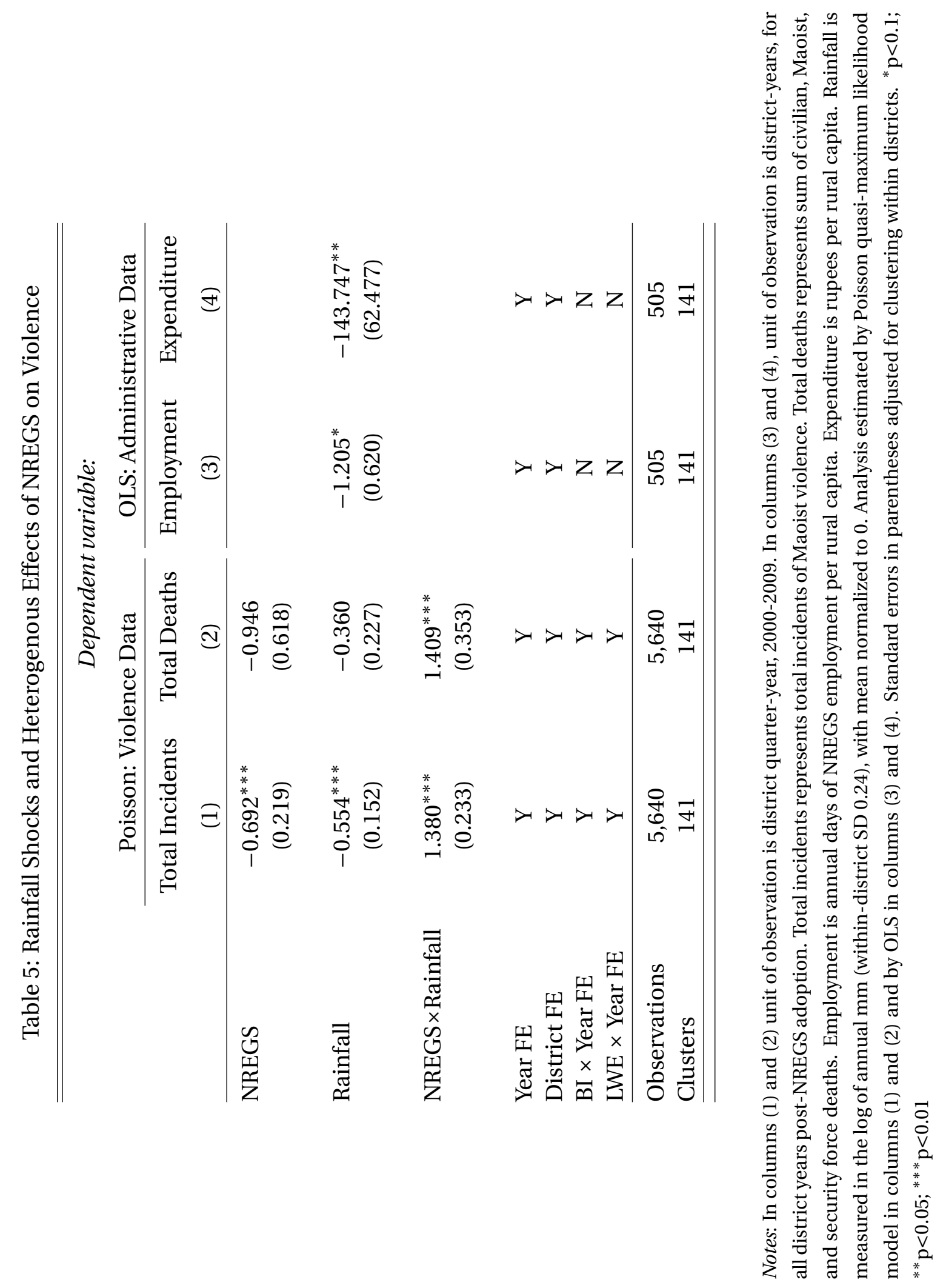


plays a particularly important role as a safety net and source of supplemental rural household income during adverse rainfall years.

In columns (3) and (4), we provide direct evidence that NREGS employment and expenditures increase during low-rainfall periods. We focus on the sample of district-years in which NREGS has already been adopted, and estimate an OLS regression of the program monitoring indicators on rainfall. ${ }^{61}$ As before, the inclusion of district fixed effects means that we identify the effects of within district rainfall variation over time i.e. rainfall shocks. The negative and statistically singificant coefficients provide additional confirmation that NREGS helps to offset negative rainfall shocks to rural household incomes by intensifying employment provision during these periods.

Overall, the relatively large responsiveness of NREGS's pacifying effects to rainfall shocks, as well as the increase in observed employment generation during these periods, are largely consistent with an income channel. The results square well with those of Fetzer, ${ }^{62}$ who shows that NREGS adoption eliminates the rainfall-violence relationship by serving as a social insurance mechanism during droughts. Our results suggest that NREGS does not reduce violence solely by mitigating rainfall shocks. Holding rainfall at average levels, NREGS adoption is estimated to cause a significant reduction of violence (which we can read off from the coefficient on the lower order NREGS adoption term, since the rainfall variable is centered at its mean), suggesting that the program's violence-reducing effects resulted from a combination of social insurance during droughts as well an overall improvement in livelihoods.

How do the rainfall results speak to potential alternative channels for NREGS's violencereducing effects? Previous research has suggested some alternative channels connecting development programs to reductions in violence. Berman et $\mathrm{al}^{63}$ for example, find that the CERP

\footnotetext{
${ }^{61}$ Since we only have annual data on NREGS employment provision, we utilize a one-year lagged measure of rainfall, since NREGS employment is provided mainly in the first two dry quarters of the year.

${ }^{62}$ Fetzer, 2014

${ }^{63}$ Berman, Shapiro and Felter, 2011
} 
program operated by the US military in Iraq reduced violence through an intelligence-gathering channel. Moreover, the infusion of fiscal resource at the local level resulting from new programs can have had complex impacts on violence, ${ }^{64}$ perhaps even pacifying violence by providing corruption as an alternative to violent extortion as a source of funding for the insurgency. Another alternative mechanism is that the setting up of an administrative apparatus for the implementation of new programs could reduce violence by expanding the reach of the state.

It is difficult to decisively rule out these competing channels, as each could potentially be correlated with the greater citizen demand for and intensity of NREGS employment provision in districts experiencing negative rainfall shocks. However, rainfall shocks are highly stochastic from year to year, and are therefore are unlikely to be correlated with the development of local administrative capacity, which requires long run investments. ${ }^{65}$ It is more difficult to rule out intelligence-gathering as a channel, which could hypothetically intensify during droughts when local populations are particularly dependent upon government programs, though qualitative information suggests that the Indian government does not actively utilize NREGS to procure informants. ${ }^{66}$ Opportunities for corruption could also expand with greater employment provision during droughts; this is a question that deserves greater research. However, our earlier findings showing that NREGS's violence-reducing effects were concentrated in high-state capacity districts, typically characterized by better service provision and lower levels of corruption, cast some doubt on this line or reasoning. Nonetheless, teasing out competing theoretical channels for the violence-reducing effects of anti-poverty programs is an important line of inquiry for further research.

\footnotetext{
${ }^{64}$ Dal Bó and Dal Bó, 2011

${ }^{65}$ Besley and Persson, 2010

${ }^{66}$ Bhatia, 2005
} 


\section{Conclusion}

Motivated by the mixed empirical record, we exploit a within-country policy experiment to study the impact of anti-poverty programs on civil conflict and the role of local state capacity in shaping these effects. Using a new panel data set on Maoist conflict violence constructed from local language press sources, we have provided evidence that the roll out of the National Rural Employment Guarantee Scheme played a major role in the pacification of the Maoist conflict in India. These pacifying effects were not uniform, however, but overwhelmingly concentrated in districts with adequate local state capacity to implement the program effectively.

The findings are important because they demonstrate the potential for anti-poverty programs to mitigate violent civil conflict, an implication that is central to a large theoretical and empirical literature connecting poverty to civil conflict but for which the literature to date provides surprisingly little empirical evidence. However, our results also show that anti-poverty programs on their own are no panacea. State capacity plays a crucial role in shaping the effects of anti-poverty programs on violence. In weak state capacity setting, it is unlikely that program benefits will pass through to local populations on the scale required to undercut popular support for insurgency and reduce the economic incentives to participate in rebellion. In high state capacity settings, however, anti-poverty programs represent a promising policy tool to combat insurgency by improving livelihoods. The findings therefore help to reconcile debates about whether weak state capacity or poverty is to blame for violent civil conflict; ${ }^{67}$ one of the ways in which weak state capacity contributes to conflict is by making government programs aimed alleviating poverty inefficacious.

More broadly, the findings suggest that a valuable topic for future research is not just whether but under what conditions anti-poverty programs reduce violence. Large-scale anti-poverty programs, ranging from workfare programs like NREGS to conditional cash transfer schemes,

\footnotetext{
${ }^{67}$ Collier and Hoeffler, 1998; Fearon and Laitin, 2003
} 
have in recent decade proliferated across developing countries. This provides an excellent opportunity to investigate how variation across settings may shape the effects of development programs on violent civil conflict, perhaps through research designs comparable to that developed in this paper - based on the staggered or partial roll-out of programs across sub-national political units. In particular, it would be valuable to investigate whether anti-poverty programs are more or less effective in diminishing support for different types of insurgencies, e.g. ethnic or nationalist rebellions versus insurgences motivated by material deprivation and inequality. ${ }^{68}$ This may additionally help to shed light on the channels through which anti-poverty programs reduce violence. For instance, while opportunity cost arguments suggest that development programs should weaken rebel recruitment in all settings, grievance theories imply that development programs should primarily be effective in mitigating insurgencies motivated by material deprivation or inequality. These are all valuable avenues for future inquiry.

\footnotetext{
${ }^{68}$ Sambanis, 2001
} 


\section{References}

Acemoglu, Daron, Camilo García-Jimeno and James A Robinson. 2015. "State Capacity and Economic Development: A Network Approach.” Am. Econ. Rev. 105(8):2364-2409.

Acemoglu, Daron and James Robinson. 2012. Why Nations Fail: The Origins of Power, Prosperity, and Poverty. Crown Business.

Angrist, Joshua D and Jörn-Steffen Pischke. 2008. Mostly Harmless Econometrics: An Empiricist's Companion. Princeton university press.

Banerjee, Sumanta. 1980. In the Wake of Naxalbari: A HIstory of the Naxalite Movement in India. Calcutta : Subarnarekha Press.

Bardhan, Pranab and Dilip Mookherjee. 2000. "Capture and Governance at Local and National Levels." Am. Econ. Rev. pp. 135-139.

Beath, Andrew, Fotini Christia and Ruben Enikolopov. 2013. "Winning Hearts and Minds Through Development: Evidence From a Field Experiment in Afghanistan.” APSA Annual Meeting Paper.

Becker, Gary. 1968. “Crime and Punishment: An Economic Approach.” The Journal of Political Economy 169:176-177.

Berg, Erlend, Sambit Bhattacharyya, Rajasekhar Durgam and Manjula Ramachandra. 2012. “Can Public Works Increase Wages? Evidence From India." University of Oxford Working Paper Series.

Berman, Eli, Jacob N Shapiro and Joseph H Felter. 2011. “Can Hearts and Minds Be Bought? The Economics of Counterinsurgency in Iraq." Journal of Political Economy 119(4):766-819.

Besley, Timothy and Torsten Persson. 2010. "State Capacity, Conflict, and Development." Econometrica 78(1):1-34.

Besley, Timothy and Torsten Persson. 2011. “The Logic of Political Violence." The Quarterly Journal of Economics 126(3):1411-1445.

Bhatia, Bela. 2005. “The Naxalite Movement in Central Bihar.” Economic and Political Weekly pp. 1536-1549.

Bhavnani, Rikhil and Bethany Lacina. 2015. "The Effects of Weather-Induced Migration On Sons of the Soil Violence in India." World Politics 67.

Blattman, Christopher and Edward Miguel. 2010. “Civil War.” J. Econ. Lit. 48(1):3-57.

Borooah, Vani K. 2008. "Deprivation, Violence, and Conflict: An Analysis of Naxalite Activity in the Districts of India." International Journal of Conflict and Violence 2(2):317-333. 
Brass, Paul R. 1997. Theft of an Idol: Text and Context in the Representation of Collective Violence. Princeton University Press.

Cederman, Lars-Erik and Kristian Skrede Gleditsch. 2009. "Introduction to Special Issue On Disaggregating Civil War.” The Journal of Conflict Resolution pp. 487-495.

Cederman, Lars-Erik, Kristian Skrede Gleditsch and Halvard Buhaug. 2013. Inequality, Grievances, and Civil War. Cambridge University Press.

Centeno, Miguel Angel. 2002. Blood and Debt: War and the Nation-State in Latin America. Penn State Press.

Chakravarti, Sudeep. 2009. Red Sun: Travels in Naxalite Country. Penguin Books India.

Collier, Paul and Anke Hoeffler. 1998. “On Economic Causes of Civil War.” Oxford Economic Papers 50(4):563-573.

Collier, Paul and Anke Hoeffler. 2004. “Greed and Grievance in Civil War.” Oxford Economic Papers 56(4):563-595.

Collier, Paul and Anke Hoeffler. 2007. "Unintended Consequences: Does Aid Promote Arms Races?*." Oxford Bulletin of Economics and Statistics 69(1):1-27.

Collier, Paul, V. L. Elliott, Havard Hegre, Anke Hoeffler, Marta Reynal-Querol and Nicholas Sambanis. 2003. Breaking the Conflict Trap: Civil War and Development Policy. World Bank Publications.

Crost, Benjamin, Joseph Felter and Patrick Johnston. 2014. "Aid Under Fire: Development Projects and Civil Conflict.” The American Economic Review 104(6):1833-1856.

Dal Bó, Ernesto and Pedro Dal Bó. 2011. "Workers, Warriors, and Criminals: Social Conflict in General Equilibrium.” Journal of the European Economic Association 9(4):646-677.

Dube, Arindrajit, Oeindrila Dube and Omar García-Ponce. 2013. “Cross-Border Spillover: US GUn Laws and Violence in Mexico.” American Political Science Review 107(03):397-417.

Dutta, Puja, Rinku Murgai, Martin Ravallion and Dominique van de Walle. 2012. "Does India’s Employment Guarantee Scheme Guarantee Employment?” Economic \& Political Weekly 47(16):55.

Easterly, William and Tobias Pfutze. 2008. "Where Does the Money Go? Best and Worst Practices in Foreign Aid." J. Econ. Perspect. 22(2).

Evans, Peter B. 1995. Embedded Autonomy: States and Industrial Transformation. Vol. 25 Cambridge Univ Press.

Eynde, Oliver Vanden. 2011. “Targets of Violence: Evidence From India's Naxalite Conflict.” NEUDC Conference Paper . 
Fearon, James D and David D Laitin. 2003. "Ethnicity, Insurgency, and Civil War." American Political Science Review 97(01):75-90.

Fetzer, Thiemo. 2014. "Social Insurance and Conflict: Evidence From India.” NEUDC Conference Paper .

Fukuyama, Francis. 2004. “The Imperative of State-Building.” Journal of democracy 15(2):17-31.

Gawande, Kishore, Devesh Kapur and Shanker Satyanath. 2015. "Renewable Resource Shocks and Conflict Intensity: Findings From India's Ongoing Maoist Insurgency.” Journal of Conflict Resolution Online Pre-print. doi: 10.1177/0022002714567949.

Gayer, Laurent and Christophe Jaffrelot. 2009. Armed Militias of South Asia: Fundamentalists, Maoists and Separatists. Columbia University Press.

Gomes, Joseph Flavian. 2015. “The Political Economy of the Maoist Conflict in India: An Empirical Analysis.” World Development 68:96-123.

Grossman, Herschel I. 1991. “A GEneral Equilibrium Model of Insurrections.” Am. Econ. Rev. 81(4):912-21.

Guha, Ramachandra. 2007. “Adivasis, Naxalites and Indian Democracy.” Economic and Political Weekly 42(32):3305-3312.

Gurr, Ted R. 1970. Why Men Rebel. Princeton University Press.

Harriss, John. 2010. “The Naxalite/Maoist Movement in India: A REview of Recent Literature.” ISAS Working Paper Series .

Hendrix, Cullen S. 2010. "Measuring State Capacity: Theoretical and Empirical Implications for the Study of Civil Conflict.” Journal of Peace Research 47(3):273-285.

Herbst, Jeffrey. 2014. States and Power in Africa: Comparative Lessons in Authority and Control. Princeton University Press.

Imbert, Clément and John Papp. 2011. Estimating Leakages in India's Employment Guarantee Using Household Survey Data. Oxford University Press chapter 9, p. 269.

Imbert, Clement and John Papp. 2015. “Labor Market Effects of Social Programs: Evidence From India's Employment Guarantee.” AEJ: Applied Economics 7(2):233-263.

Iyengar, Radha, Jonathan Monten and Matthew Hanson. 2011. "Building Peace: The Impact of Aid On the Labor Market for Insurgents.” NBER Working Paper .

Johnson, Chalmers. 1982. MITI and the JapanEse Miracle: The Growth of Industrial Policy: 19251975. Stanford University Press.

Kalyvas, Stathis N. 2006. The Logic of Violence in Civil War. Cambridge University Press. 
Kalyvas, Stathis N. 2008. Order, Conflict and Violence. Cambridge University Press chapter 16 Promises and Pitfalls of an Emerging Research Program: the Microdynamics of Civil War.

Kapur, Devesh and Pratap Bhanu Mehta. 2007. Public Institutions in India: Performance and Design. Oxford University Press.

Keefer, Philip and Stuti Khemani. 2009. "When Do Legislators Pass On Pork? The Role of Political Parties in Determining Legislator Effort.” American Political Science Review 103(01):99112.

Khanna, Gaurav and Laura Zimmermann. 2014. "Guns and Butter? Fighting Violence with the Promise of Development.” NEUDC Conference Paper .

Kohli, Atul. 2004. State-Directed Development: Political Power and Industrialization in the Global Periphery. Cambridge University Press.

Migdal, Joel S. 1988. Strong Societies and Weak States: State-Society Relations and State Capabilities in the Third World. Princeton University Press.

Miguel, Edward, Shanker Satyanath and Ernest Sergenti. 2004. "Economic Shocks and Civil Conflict: An Instrumental Variables Approach.” Journal of Political Economy 112(4):725-753.

Mukherjee, Shivaji. 2013. Colonial Origins of Maoist Insurgency in India: Historical Legacies of British Indirect Rule. In APSA Annual Meeting Paper.

Nayyar, Rohini. 2003. Identification of Districts for Wage and Self Employment Programmes. Planning Commission.

Niehaus, Paul and Sandip Sukhtankar. 2013. "Corruption Dynamics: The Golden Goose Effect.” American Economic Journal: Economic Policy 5(4):230-269.

Nielsen, Richard A, Michael G Findley, Zachary S Davis, Tara Candland and Daniel L Nielson. 2011. "Foreign Aid Shocks As a Cause of Violent Armed Conflict." American Journal of Political Science 55(2):219-232.

Nunn, Nathan and Nancy Qian. 2014. “US Food Aid and Civil Conflict.” The American Economic Review 104(6):1630-1666.

O’Donnell, Guillermo A. 1999. Counterpoints: Selected Essays On Authoritarianism and Democratization. Univ of Notre Dame Pr.

Pandita, Rahul. 2011. Hello Bastar. Westland.

Pritchett, Lant. 2009. "Is India a Flailing State?: Detours On the Four Lane Highway to Modernization.".

Sambanis, Nicholas. 2001. “Do Ethnic and Nonethnic Civil Wars Have the Same Causes?" Journal of Conflict Resolution 45(3):259-282. 
Scott, James C. 1969. “Corruption, Machine Politics, and Political Change.” The American Political Science Review 63(4):1142-1158.

Skocpol, Theda. 1985. Bringing the State Back In. Cambridge University Press Cambridge.

Staniland, Paul. 2014. Networks of Rebellion: Explaining Insurgent Cohesion and Collapse. Cornell University Press.

Varshney, Ashutosh. 2003. Ethnic Conflict and Civic Life: Hindus and Muslims in India. Yale University Press.

Verghese, Ajay and Emmanuel Teitelbaum. 2011. "Colonialism and Armed Conflict in the Indian Countryside." APSA Annual Meeting Paper .

Weiner, Myron. 1978. Sons of the Soil: Migration and Ethnic Conflict in India. Princeton University Press.

Weinstein, Jeremy M. 2006. Inside Rebellion: The Politics of Insurgent Violence. Cambridge University Press.

Wilkinson, Steven I. 2006. Votes and Violence: Electoral Competition and Ethnic Riots in India. Cambridge University Press.

Wooldridge, Jeffrey M. 1999. "Distribution-Free Estimation of Some Nonlinear Panel Data Models.” Journal of Econometrics 90(1):77-97. 